\title{
Education as a Resource for Development of the Commonwealth of Independent States
}

\author{
Aleksander Mikhailovich Fedorov ${ }^{11}$, Nadezhda Anatolyevna Bogdanova ${ }^{2}$, Elvira \\ Elemesovna Fayzulina ${ }^{3}$, Elionora Anatolyevna Khapalazheva', and Ekaterina Anatolyevna \\ Yakovleva $^{4}$ \\ ${ }^{1}$ Moscow State Pedagogical University, Institute of Social Studies and Humanities, Department of \\ Theory of Economics and Management, Moscow, Russia \\ ${ }^{2}$ Petrozavodsk State University, Institute of Pedagogy and Psychology, Department of Theory and \\ Methods of Compulsory and Professional Education, Petrozavodsk, Republic of Karelia, Russia \\ ${ }^{3}$ Moscow State Institute of Culture, Faculty of State Cultural Policy, Department of Pedagogy, \\ Psychology and Philosophy, Khimki, Russia \\ ${ }^{4}$ Petrozavodsk State University, Institute of Foreign Languages, Department of German and French, \\ Petrozavodsk, Republic of Karelia, Russia
}

\begin{abstract}
The article represents the analysis of modern integration processes in the field of education in the Commonwealth of Independent States (CIS). As it is stated in the article, globalization, global transformation, and integration of countries actualize the problems of developing common approaches and strategies to improve the quality of education and to meet the new challenges of the developing post-industrial society based on knowledge, information, and innovations. The role of human capital is increasing under quite new conditions of cultural, social, economic, and technological development of the members of the CIS. One of the central ideas of the article is the problem of improving national systems of compulsory and professional education as the main resources to harmonize them due to the interests of the CIS and to increase the quality of the training of personnel, the development of their academic and socio-professional mobility of the population in these countries. The aim is to ensure the competitiveness of the national education systems of the CIS in the global education market. Cooperation in the field of pedagogical and educational sciences and teacher training has significantly intensified. The Russian language plays a special role in the integration processes in the CIS. The present-day tendencies and strategies of the development of the common CIS education space are characterized in the article.
\end{abstract}

Keywords: compulsory and professional education, national system of education, harmonization, integration, common education space

\section{Introduction}

\footnotetext{
${ }^{1}$ Corresponding author: am.fedorov@mpgu.su
} 
In modern conditions of globalization, global transformation and innovations education becomes one of the key factors of cultural, social and economic development of nations. It influences greatly on the level and quality of life of people. Education plays an important role in the creation, support and development of innovations, tightly connected with new technological opportunities as well as with the cultural, social, economic and technological progress of the society and the state [1].

"The creation of a common educational and cultural space should directly affect the reduction of costs and increase the competitiveness of CIS producers, since the CIS members remain mutual consumers of each other's products and services, and this trend is likely to increase in the future" [2].

The civilization of the beginning of the $21^{\text {st }}$ century experiences a great influence of a rather inconsistent and complicated situation of cultural, social and economic instability, turbulence and uncertainty. The processes of deformation of traditional fundamental paradigms, cultures, concepts, cultural and social institutions, values and meanings, that have previously ensured the integrity of the socio-cultural space of human life have been increasing for the last decade [3-5]. It becomes quite evident that "sustainable and dynamic social and economic development under the conditions of volatility, uncertainty, complexity and ambiguity (the VUCA-world) determined by globalization is inextricably linked with the problem of formation of a new generation [6].

A wide range of problems of modern education has been studied and analyzed by many researchers in the CIS [2, 7-12] and in other countries [13-16].

The purpose of this article is to analyze the key problems, drivers, trends and strategies of the development of the common CIS education space.

\section{Results}

The Commonwealth of Independent States (CIS) celebrates its 30th anniversary. Since the establishment of the CIS in 1991, education has been one of the priorities of interstate relations of the CIS. At the same time, education has become one of the major factors and tools for the national security and stability of the Commonwealth of Independent States, increasing their competitiveness and international authority in the changing and globalizing multipolar world.

For 30 years, the joint efforts of the heads of state, parliaments and governments of the CIS member states, scientific and professional pedagogical communities, as well as the leading educational organizations of the CIS have carried out systematic work on the harmonization of state educational policies and national systems of education to form a common CIS education space on the basis of the established principles of interstate relations.

The priority areas of cooperation between the CIS countries in the field of education have been developed and successfully implemented and effectively harmonized. The practice of education management and leadership has been improved recently.

By the decision of the Council of Heads of Governments of the CIS in 1997, the Concept of the Formation of a Common Educational Space of the Commonwealth of Independent States was approved as a regulatory and legal basis for the further development of integration processes in the CIS.

Later on, the Concept for the Development of Adult Education in the Commonwealth of Independent States was approved in 2006, the Concepts for the Development of Distance Learning and the IT implementation in education were approved in 2007. 
The implementation of the decisions of the Congresses of Teachers and Educators of the CIS (Astana, 2010, Yerevan, 2012, Minsk, 2014, Moscow, 2016, Bishkek, 2018) had a positive impact on the development of innovative processes in the field of education. One of the most important achievements of the congresses mentioned above is the recognition of the fact that education is a determinant of the development of human capital, the formation of a modern society and an innovative economy based on knowledge in the CIS. The unity of approaches of the professional-pedagogical community to the understanding that the core of the quality of education in modern conditions is the culture of education, correlates with the quality of human life, high levels and criteria of its development.

The harmonization of state educational policies of the CIS and the formation of a common education space of the Commonwealth of Independent States were accompanied by:

- systemic changes in educational goals as a result of social and cultural transformation of the present-day society and socio-cultural practices of a person. This includes changes in the very nature of work, socio-economic relations and human behavior patterns in the evolving the knowledge-based economies of the CIS;

- systemic changes associated with the expansion of the "age boundaries" of education in the CIS member states, the growing diversity of the population this area covers ("Life Long Learning", academic mobility of students, socio-professional mobility of graduates, heads of educational organizations and teaching staff), as well as demographic "shifts" (urbanization, "demographic pits", labor immigration);

- systemic changes associated with the formation of new educational paradigms and new concepts and technologies of teaching and learning, including the possibilities and opportunities of e-learning on the basis of educational platforms.

All mentioned above-determined success of national systems of education in the CIS in their transition from the paradigm of the "unified Soviet school" to the paradigm of openness and diversity of ways of development in education.

Over the years of cooperation and international cooperation of the CIS member states in the field of education, the practice of interstate dissemination of innovative experience of teachers, professional-pedagogical communities, and educational organizations has been further developed and deepened.

Cooperation in the field of pedagogical and educational sciences and teacher training has significantly intensified. The coordinating and consolidating role in these processes is played by the Russian Academy of Education and the Moscow State Pedagogical University (MPSU), which initiated the creation of the Eurasian Association of Pedagogical Universities. Ministers of Foreign Affairs of the CIS decided to nominate the MPSU as a basic university of the CIS in the field of life-long teacher training.

The Russian language plays a special role in the integration processes in the Commonwealth of Independent States, as the language of interethnic communication and one of the basic tools for building a common educational space in the CIS.

Currently, Russian is the 6th most widely spoken language in the world. More than 300 million people speak Russian in the world, including 140 million who consider it their native language. Russian is the official or working language of many authoritative international organizations, including the Commonwealth of Independent States (CIS), the Eurasian Economic Union, and the Collective Security Treaty Organization. Russian is, along with Belarusian, the official language of the Republic of Belarus. In the Republic of Kazakhstan and the Kyrgyz Republic, it has the status of an official language, and in the Republic of Moldova, it is the language of interethnic communication. 
In the context of the new language situation that has developed as a result of the collapse of the USSR, the member countries of the Commonwealth of Independent States are increasingly aware of the need to support the Russian language as a means of interethnic communication in most of the post-USSR area. The total number of students studying in Russian in the former republics of the Soviet Union is about 3.2 million people. In the Republic of Armenia, Russian is a compulsory subject in schools from 2nd to 12th grade. Education in Russian is widely available in the Republic of Belarus ( $9 \%$ of the population is Russian), the Republic of Kazakhstan (24\%) and Moldova (6\%).

According to the decision of the heads of the CIS, the Public Council of the basic organization of the CIS for the Russian Language was established in 2014. It includes prominent scientists and representatives of the professional-pedagogical community of Armenia, Belarus, Kazakhstan, Kyrgyzstan, Moldova, Russia, and Tajikistan. The Russian language is being supported and popularized in the CIS within the framework of the Federal Target Program “The Russian Language” for the period of 2016-2020.

\section{Discussion}

Thus, it can be stated that over the years of its existence (1991-2021), the Commonwealth of Independent States has formed the principles of new interstate relations in the post-Soviet space, and the practice of cooperation within the CIS has confirmed that the Commonwealth countries have wide opportunities for the development of mutually beneficial and equal cooperation in the field of education.

The nature and dynamics of systemic changes in the development of national education systems and the unified (common) educational space of the Commonwealth of Independent States currently fully correspond to global challenges and trends in the development of education: education acts as a key factor in the development of the innovative capacity of human capital, and the quality of education is considered as the most important component of the quality of human life, which is inextricably linked with the further success of a developing individual in the modern and future world.

The positive experience of reforming and modernizing national education systems in the CIS confirms a special impact of mutually beneficial international collaboration and cooperation in the interests of improving the national educational systems of the Commonwealth of Independent States.

The cooperation of the CIS countries in the field of education has contributed to the progressive, dynamic and sustainable socio-economic development, the formation of the human capital of national economies, the support and development of the cultures of the peoples living in the Commonwealth of Independent States.

At the same time, it is of strategic importance for the further progressive socio-economic development of the CIS. It is designed to ensure the development of the main directions of education reform for the period up to 2030 and the conditions for the advanced development of the common CIS education space as a key factor in the formation of the human capital of modern society and an innovative economy based on knowledge.

\section{Conclusion}

The most important focus of the next steps in the strategic development of the common CIS education area is the idea of full support for educational initiatives, innovations and 
leadership as strategic resources for achieving a new quality of education and sustainable development of the national systems of education in the CIS for the period up to 2030.

\section{References}

1. E. Akimova, N. Korshunova, A. Fedorov, et al., New Challenges in Changing Times: The Digital Education Support for Finance Literacy Education, in Education and City: education and Quality of Living in the City. The Third Annual International Symposium, Moscow, August 24-26, 5020 (Moscow, 2020) - SHS Web of Conferences 98, 05020 (2021). - DOI: 10.1051/shsconf/20219805020

2. A.N. Asaul, Econ. Rev. Rus. 3(21), 3-7 (2009)

3. V. Stepin, Chelovek. Deyatelnost. Kultura [Man. Activity. Culture] (Saint-Petersburg University of the Humanities and Social Sciences, Saint-Petersburg, 2018)

4. V. Lektorskiy, Chelovek i kultura: izbrannye stati [Man and Culture: selected articles] (SPbGUP, Saint-Petersburg, 2018)

5. D. Newman, Top 6 Digital Transformation Trends in Education (2017). Accessed on: December 16, 2020. [Online]. Available:

https://www.forbes.com/sites/danielnewman/2017/07/18/top-6-digital-transformation-t rends-in-education/\#12cf69812a9a.

6. R. Patton, R. Santos, The Next-Generation Digital Learning Environment and a Framework for Change for Educational Institution (Cisco Education Lead, Latin America 2018). Accessed on: July 20, 2021. [Online]. Available:

https://www.cisco.com/c/dam/en_us/solutions/industries/docs/education/digital-learnin g-environment.pdf

7. Obshchee obrazovatelnoe prostranstvo EAES kak zalog uspekha evraziiskoi ekonomicheskoi integratsii [Common Educational Space of EAE as a Prerequisite of Eurasian Economic Integration]. Accessed on: July 20, 2021. [Online]. Available: https://www.mk.ru/migrants-in-russia/2016/12/29/obshhee-obrazovatelnoe-prostranstv o-eaes-kak-zalog-uspekha-evraziyskoy-ekonomicheskoy-integracii.html

8. I.D. Froumin, M.S. Dobryakova, K.A. Barannikov, I.M. Remorenko, Key competences and new literacy: from slogans to school reality. Modern education analytics, 19, (Institute of Education of Higher School of Economics, Moscow, 2018)

9. M.A. Chavykina, Creat.Econ. 11(9), 931-942 (2017)

10. V.M. Filippov, Vestnik RUDN. Ser.: Int. Rel. 15(3), 203-211 (2015)

11. I.D. Frumin, M.S. Dobryakova, K.A. Barannikov, I.M. Remorenko, Universalnye kompetentnosti i novaya gramotnost: chemu uchit segodnya dlya uspekha zavtra. Predvaritelnye vyvody mezhdunarodnogo doklada o tendentsiyakh transformatsii shkolnogo obrazovaniya [Universal competencies and new literacy: what to teach today for tomorrow's success. Preliminary conclusions of the international report on trends in the transformation of school education] (NIU VShE, Moscow, 2018)

12. N.V. Karmazina, A.M. Fedorov, Obrazovanie dlya XXI veka: novye vyzovy v usloviyakh sistemnykh izmenenii [Education for the 21st Century: New Challenges under Systemic Changes], in A.Yu. Nagornova (ed.), Development of Modern Higher Education in Russia and Abroad (Ulyanovsk, 2020)

13. S. Baller, S. Dutta, B. Lanvin (eds.), The Global Information Technology Report 2016. Innovating the Digital Economy. Insight Report. Accessed on: July 20, 2021. [Online]. Available: http://www3.weforum.org/docs/GITR2016/WEF_GITR_Full_Report.pdf

14. T. Barkatsas, A. Bertram (eds.), Global Learning in the $21^{\text {st }} \bar{C}$ entury (Sense Publishers, Boston, MA, 2016) 
15. J. Conrads, M. Rasmussen, N. Winters, A. Geniet, L. Langer, Digital Education Policies in Europe and Beyond. Key Design Principles for More Effective Policies. Accessed on: July 20, 2021. [Online]. Available: https://doi.org/10.2760/462941

16. Tiven M., Fuchs E., Bazari A. \& MacQuarrie A. (2018). Evaluating Global Digital Education: Student Outcomes Framework. New York, NY: Bloomberg Philanthropies and the Organisation for Economic Co-operation and Development. 